\title{
НА ПУТИ СОВЕРШЕНСТВОВАНИЯ РЕГИОНАЛЬНОЙ СТРАТИГРАФИЧЕСКОЙ ШКАЛЫ ПЕРМИ СЕВЕРО-ВОСТОКА РОССИИ: РЕЗУЛЬТАТЫ И ДОСТИЖЕНИЯ ПОСЛЕДНИХ ЛЕТ
}

\author{
А. С. Бяков, И. Л. Ведерников, И. В. Брынько \\ ФГБУН Северо-Восточный комплексный научно-исследовательский институт \\ им. Н. А. Шило ДВО РАН, г. Магадан \\ E-mail: abiakov@mail.ru
}

\begin{abstract}
Проблема трансрегиональной корреляции Региональной стратиграфической шкалы перми Северо-Востока России (РСШ) до сих пор остается одной из наиболее трудных задач региональной геологии северо-восточной Азии. Лишь в последнее время благодаря использованию методов прецизионного (CA ID-TIMS и SHRIMP-II) U-Pb датирования цирконов из синхронных осадконакоплению туфов и методов изотопной хемостратиграфии $\delta^{13} \mathrm{C}_{\text {орг. }}$ достигнут значительный прогресс в этом направлении. Впервые удалось обоснованно определить положение границы перми и триаса в ее современном понимании и принципиально уточнить соответствие ярусов верхней перми РСШ и Международной стратиграфической шкалы (МСШ) перми. Установлен также наиболее молодой (позднечансинский) комплекс двустворчатых моллюсков суперрегиона.
\end{abstract}

Ключевые слова: Региональная стратиграфическая шкала, пермь, прецизионное $\mathrm{U}-\mathrm{Pb}$ датирование цирконов, хемостратиграфия, изотопия $\delta^{13} \mathrm{C}_{\text {орг. }}$, Северо-Восток России.

DOI: $10.34078 / 1814-0998-2020-1-47-56$

\section{ВВЕДЕНИЕ}

Пермский период является одним из наиболее сложных и наименее изученных этапов геологического развития Земли в целом и СевероВостока Азии в частности. В северо-восточном регионе сохранились уникальные по своей полноте и разнообразию стратиграфические последовательности, в которых «записана» разнообразная геологическая информация этого времени. Пестрый спектр фаций, обусловленный как геократической природой и резкой климатической дифференциацией, так и различием пермских геодинамических обстановок, еще резче подчеркивается спецификой отдельных седиментационных бассейнов.

В течение перми, особенно в конце периода, произошли крупные биосферные события, в том числе крупнейшее в истории Земли вымирание, причины и конкретное проявление которого в различных бассейнах и в разных группах биоты привлекают пристальное внимание ученых разных специальностей. Поэтому расшифровка пермской геологической истории северо2020

(С) Бяков А. С., Ведерников И. Л., Брынько И. В., восточной Азии представляется весьма актуальной и невозможна без детальной и хорошо обоснованной региональной стратиграфической шкалы, обладающей большим корреляционным потенциалом.

В последние несколько лет были получены многочисленные новые материалы, дополняющие наши знания по стратиграфии перми Северо-Востока России и в значительной степени увеличивающие корреляционный потенциал РСШ; обзору этих материалов и посвящена настоящая статья.

\section{СОВРЕМЕННОЕ СОСТОЯНИЕ РСШ ПЕРМИ СЕВЕРО-ВОСТОКА РОССИИ И ПРОБЛЕМЫ ЕЕ КОРРЕЛЯЦИИ}

РСШ перми Северо-Востока России отражает единственную в нашей стране полную стратиграфическую последовательность пермских морских отложений и поэтому во многом уникальна. По степени своей обоснованности и насыщенности окаменелостями она не имеет аналогов во всей восточной части Бореальной биогеографической надобласти. Биостратиграфической основой этой шкалы являются три достаточно быстро эволюционирующие группы фауны - брахиопо- 
ды, двустворчатые моллюски и мелкие фораминиферы, а в нижней и низах средней перми - и аммоноидеи (Ganelin, Biakov, 2006; Kutygin, 2006). Поэтому не случайно, что РСШ перми СевероВостока России служит своего рода эталоном при корреляции всех бореальных пермских отложений не только северо-восточной России, но и ряда прилегающих регионов - Северной и Центральной Монголии, Забайкалья, Новосибирских островов, севера Сибири, Таймыра и Новой Земли.

В то же время значительный эндемизм северовосточно-азиатской пермской фауны, среди которой практически полностью отсутствуют конодонты и фузулиниды - ортостратиграфические группы для позднего палеозоя, не позволяет напрямую коррелировать большую часть региональных стратонов перми Северо-Востока России с ярусами МСШ перми. Поэтому проблема трансрегиональных корреляций остается одной из самых труднорешаемых задач региональной геологии северо-восточной Азии.

Особенно остро стоит задача точного датирования большей части среднепермских и верхнепермских (вучапинско-чансинских) отложений региона, поскольку непосредственные биостратиграфические корреляции северо-восточно-азиатских разрезов этого возраста с ярусами МСШ невозможны из-за отсутствия в разрезах Северо-Востока России не только конодонтов и фузулинид, но и аммоноидей - важнейших групп фауны при проведении меж- и трансрегиональных корреляций.
Учитывая сказанное, можно констатировать, что существует лишь один путь к решению обозначенной проблемы - широкое использование прецизионного радиоизотопного датирования реперных стратиграфических уровней и современных методов хемостратиграфии. Весьма актуальной остается также задача дальнейшего совершенствования биостратиграфических шкал по разным группам фауны.

\section{ПРЕЦИЗИОННОЕ РАДИОИЗОТОПНОЕ U-Pb ДАТИРОВАНИЕ ЦИРКОНОВ ИЗ СИНХРОННЫХ ОСАДКОНАКОПЛЕНИЮ ТУФОВ}

Благодаря прецизионному U-Pb датированию цирконов, выделенных из синхронных осадконакоплению туфов, в настоящее время удалось получить ряд важных реперных датировок средне- и верхнепермских отложений из нескольких ключевых разрезов (рис. 1). Основные материалы были получены нами при изучении разрезов восточного обрамления Охотского массива и Аян-Юряхского антиклинория (Davydov et al., 2016, 2018; Isbell et al., 2016; Бяков и др., 2017a) - рис. 2.

В первом районе методом CA-IDTIMS датированы цирконы, выделенные из четырех проб бентонитов: двух из аналогов роудского яруса (русско-омолонский и олыньский региональные горизонты) и двух - из аналогов вучапинского яруса (нижняя половина хивачского регионального горизонта).

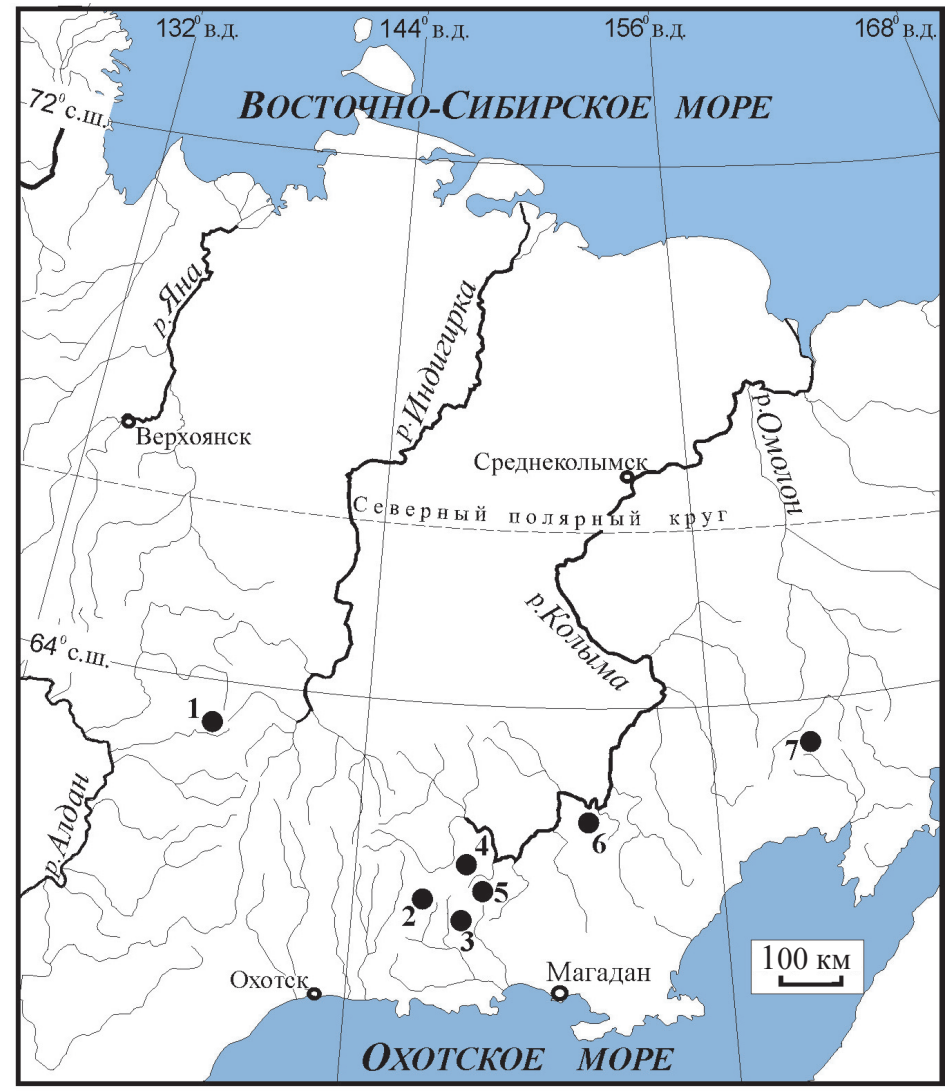

Рис. 1. Расположение основных разрезов пермских отложений, из которых получены новые данные по U-Pb датированию цирконов, изотопии $\delta^{13} \mathrm{C}_{\text {орг. }}$ и ископаемой фауне: 1 - Южное Верхоянье, басс. р. Сеторым; 2, 3 - восточное обрамление Охотского массива: 2 - р. Дружба, приток р. Бургагылкан; 3 - руч. Пластовый, приток р. Хурэн; 4, 5 Аян-Юряхский антиклинорий: 4 - р. Омчак, приток р. Тенке, 5 - правобережье верхнего течения р. Тенке; 6 - Балыгычанский блок, верховья р. Паутовая; 7 - Омолонский массив, руч. Водопадный, приток р. Хивач

Fig. 1. Location of the main sections of Permian deposits, from which new data on $\mathrm{U}-\mathrm{Pb}$ dating of zircons, isotopy $\delta^{13} \mathrm{C}_{\text {org }}$, and fossil fauna were obtained: 1 - Southern Verkhoyanye, Setorym River; 2, 3 - eastern frame of the Okhotsk massif: 2 - Druzhba River, Burgagylkan River tributary; 3 - Plastovyi Creeck, Khuren River tributary; 4, 5 - Ayan-Yuryakh anticlinorium: 4 - Omchak River, Tenke River tributary, 5 - right bank of the Tenke River; 6 Balygychan block, Pautovaya River; 7 - Omolon massif, Vodopadnyi Creeck, Khivach River tributary 
Puc. 2. Региональная стратиграфическая шкала средней - верхней перми Северо-Востока России и основные датированные уровни

Fig. 2. Regional stratigraphic scale of the Middle-Upper Permian of Northeast Russia and the main dated levels

Возраст наиболее древней датированной пробы, происходящей из бивальвиевой зоны Kolymia inoceramiformis (Бяков, 2012), где встречены роудские амммоноидеи Sverdrupites aff. harkeri (Ruzhencev), брахиоподы Mongolosia russiensis (Zavodowsky) и двустворчатые моллюски Kolymia inoceramiformis Licharew, составил $274.0 \pm 0.12$ млн лет. Возраст образца, отобранного стратиграфически выше по разрезу из зоны Kolymia plicata, охарактеризованной находками вида-индекса, определен как $273.1 \pm 0.1$ млн лет. Таким образом, впервые точно датирована нижняя часть омолонского регионального надгоризонта, которая, в частности, определяется появлением аммоноидей свердрупитового комплекса, брахиопод-монголозий и двустворок-колымий.

Эти данные позволяют провести датирование стратонов омолонского надгоризонта РСШ и поставить вопрос об уточнении (в этом интервале) МСШ. Проведенный В. И. Давыдовым с коллегами обзор кунгурско-вордских последовательностей в основных хорошо изученных регионах мира (Davydov et al., 2018) позволяет предположить, что основание роудского яруса может быть датировано примерно 277 млн лет, а граница роудского и вордского ярусов - около 271 млн лет.

Такое предположение в целом подтверждается недавней датировкой методом SHRIMP-II цирконов из прослоя бентонитового туфа, обнаруженного в самых верхах джигдалинской свиты (в 4.5 м ниже ее кровли) опорного разреза по руч. Левый Водопадный (6305'47" с. ш., $159^{\circ} 18^{\prime} 58^{\prime \prime}$ в. д.) Омолонского массива. Этот интервал разреза, относящийся к бивальвиевой зоне Aphanaia dilatata (нижняя часть роудского яруса и русско-омолонского горизонта), ранее был охарактеризован аммоноидеями Sverdrupites harkeri (Ruzhencev) (Решения..., 2009), брахиоподами Mongolosia russiensis (Zavodowsky) и двустворчатыми моллюсками Aphanaia dilatata Biakov

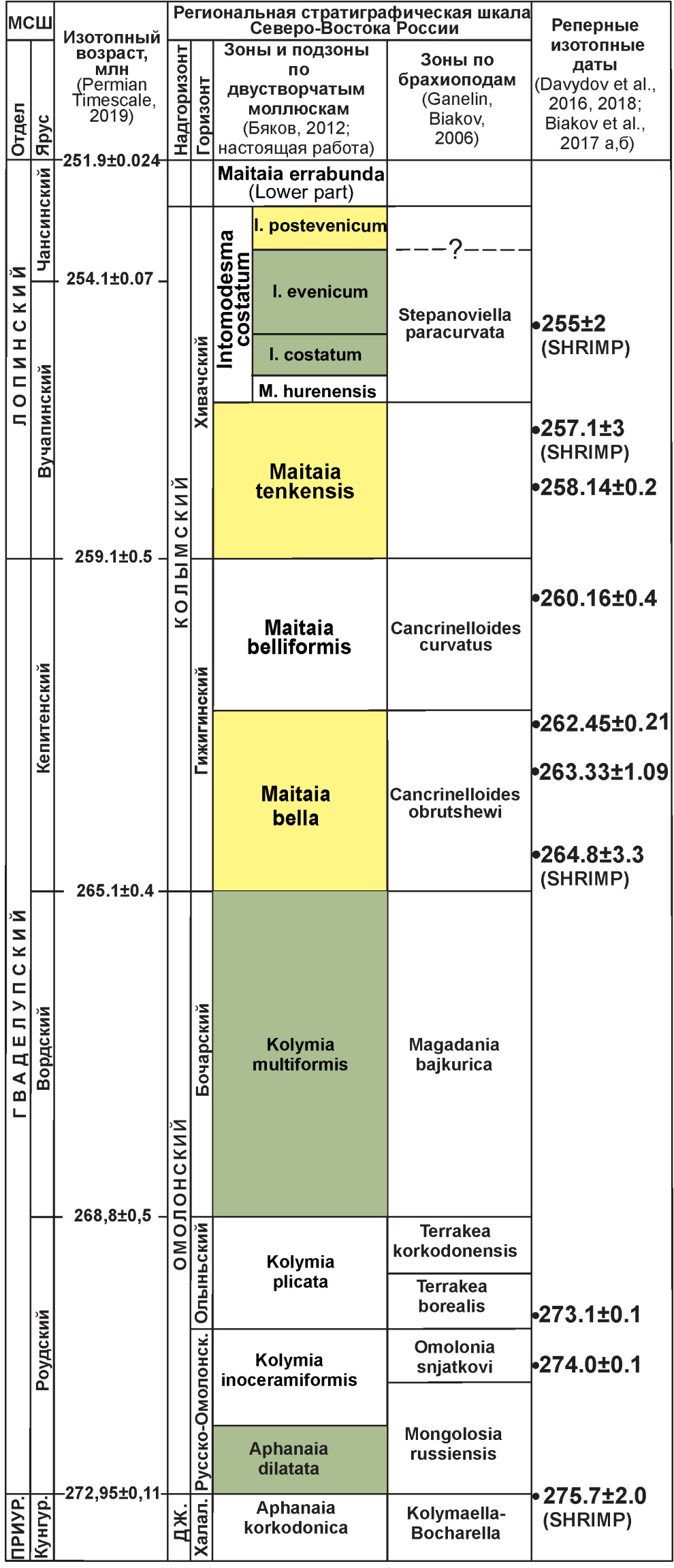

и Kolymia sp. (Кашик и др., 1990). Конкордантный возраст изученного образца туфов составил $275.7 \pm 2$ млн лет (Брынько и др., 2019). 
С учетом того, что руководящие остатки ископаемой фауны зоны Aphanaia dilatata найдены непосредственно выше прослоя рассматриваемого туфа, мы принимаем датировку нижней границы роудского яруса чуть моложе полученной даты (см. рис. 2).

Из разреза по р. Дружба (восточное обрамление Охотского массива) проведено датирование туфа из атканской свиты непосредственно выше нижней границы гижигинского регионального горизонта (Davydov et al., 2018). Здесь же собрана характерная фауна: двустворчатые моллюски Maitaia cf. bella Biakov и брахиоподы Cancrinelloides cf. ochotica Zavodowsky. Определенный возраст наиболее молодого зерна (возраст осадконакопления) составил $263.33 \pm 1.09$ млн лет, что несколько моложе изотопного возраста современной границы кепитенского и вордского ярусов (265.1 \pm 0.4 млн лет) - Permian..., 2019.

Еще две датировки $(260.16 \pm 0.4$ и $258.14 \pm 0.2$ млн лет) получены из прослоев бентонитовых туфов из верхов гижигинского (первая датировка) и низов хивачского регионального горизонта РСШ перми - см. рис. 2. Вторая датировка подтверждает ранее полученную SHRIMP-II дату из АянЮряхского антиклинория (Бяков и др., 2017a, см. ниже).

В Аян-Юряхском антиклинории методом CA-IDTIMS датирован прослой туфа из средней части атканской свиты - 262.45 \pm 0.21 млн лет (Davydov et al., 2016). Тем самым подтверждена правильность сопоставления гижигинского горизонта с кепитенским ярусом МСШ, ранее обоснованная палеонтологически (Ganelin, Biakov, 2006; Бяков, 2007).

Из непрерывного стратотипического разреза средней - верхней перми Аян-Юряхского антиклинория, ранее изученного нами (Бяков, Ведерников, 1990; Бяков, 2007), методом SHRIMP-II получена датировка цирконов из прослоя пеплового литокристаллокластического туфа кислого состава (Бяков и др., 2017а). Положение образца контролируется руководящей фауной брахиопод и двустворок по всему разрезу (нижняя часть хивачского регионального горизонта РСШ перми Северо-Востока России, бивальвиевая зона Маіtaia tenkensis). Это позволило получить важный реперный уровень в верхнепермской части РСШ перми. Полученная датировка 257.1 \pm 3.0 млн лет хорошо согласуется со стратиграфическим положением изученного образца и позволяет отнести вмещающие отложения к нижней части вучапинского яруса МСШ пермской системы.

Очень важная дата была получена также для верхневучапинских отложений запада Балыгычанского блока (Бяков и др., 2017б). Здесь методом SHRIMP-II датированы цирконы из прослоя литокристаллокластического туфа средне- го состава из разреза нижней части паутовской свиты, охарактеризованной в нижней части двустворчатыми моллюсками Intomodesma sp. indet., I. ex gr. costatum Popow; в кровле паутовской свиты найдены остатки двустворок Intomodesma postevenicum Biakov и гастропод Straparolus sp., a в основании гербинской свиты - Claraioides aff. primitivus (Yin). Полученный изотопный возраст $(255 \pm 2$ млн лет) близок к современной границе вучапинского и чансинского ярусов МСШ пермской системы - 254.1 млн лет. Исходя из распределения остатков двустворок в изученных разрезах, их соотношения со стратиграфическим положением рассматриваемого и ранее датированных образцов из Аян-Юряхского антиклинория и северо-восточного обрамления Охотского массива, а также с учетом проведенной межрегиональной корреляции недавно полученной нами записи содержания изотопа $\delta^{13} \mathrm{C}_{\text {орг. }}$ в глинистых породах, можно уверенно предполагать, что большая часть региональной бивальвиевой зоны Intomodesma costatum отвечает верхней части вучапинского яруса, а чансинскому ярусу на северо-востоке Азии соответствует лишь верхняя часть бивальвиевой зоны Intomodesma costatum в объеме верхней части подзоны Evenicum и подзоны Postevenicum и часть отоцерасовых слоев в объеме зоны Otoceras concavum (низы бивальвиевой подзоны Errabunda) - см. рис. 2.

Перечисленные датировки из аналогов вучапинского яруса - нижней и верхней частей хивачского регионального горизонта РСШ очень важны, поскольку на протяжении нескольких десятилетий многие исследователи подвергали сомнению присутствие на Северо-Востоке Азии самых верхних горизонтов пермской системы (Ганелин, Котляр, 1984; Durante, 2007).

\section{ХЕМОСТРАТИГРАФИЯ $\Delta^{13} \mathrm{C}_{\text {ОРГ }}$ ГЛИНИСТЫХ ПОРОД}

Одним из наиболее информативных методов сопоставления разрезов пермских и пограничных пермо-триасовых отложений является хемостратиграфия $\delta^{13} \mathrm{C}_{\text {орг. }}$ глинистых отложений, получившая в последнее время широкое распространение (Krull et al., 2000; Grasby, Beauchamp, 2008; Grasby et al., 2015; и др.). Этот метод позволяет проводить глобальную корреляцию разрезов, что делает его универсальным инструментом современной стратиграфии.

Благодаря использованию хемостратиграфии $\delta^{13} \mathrm{C}_{\text {орг. }}$ впервые на Северо-Востоке России удалось определить современное положение границы перми и триаса как в относительно мелководных (Южное Верхоянье - Захаров и др., 2014, 2015; Бяков и др., 2016), так и глубоководных (запад Балыгычанского блока - Бяков и др., 2017в) фациях - рис. 3. 


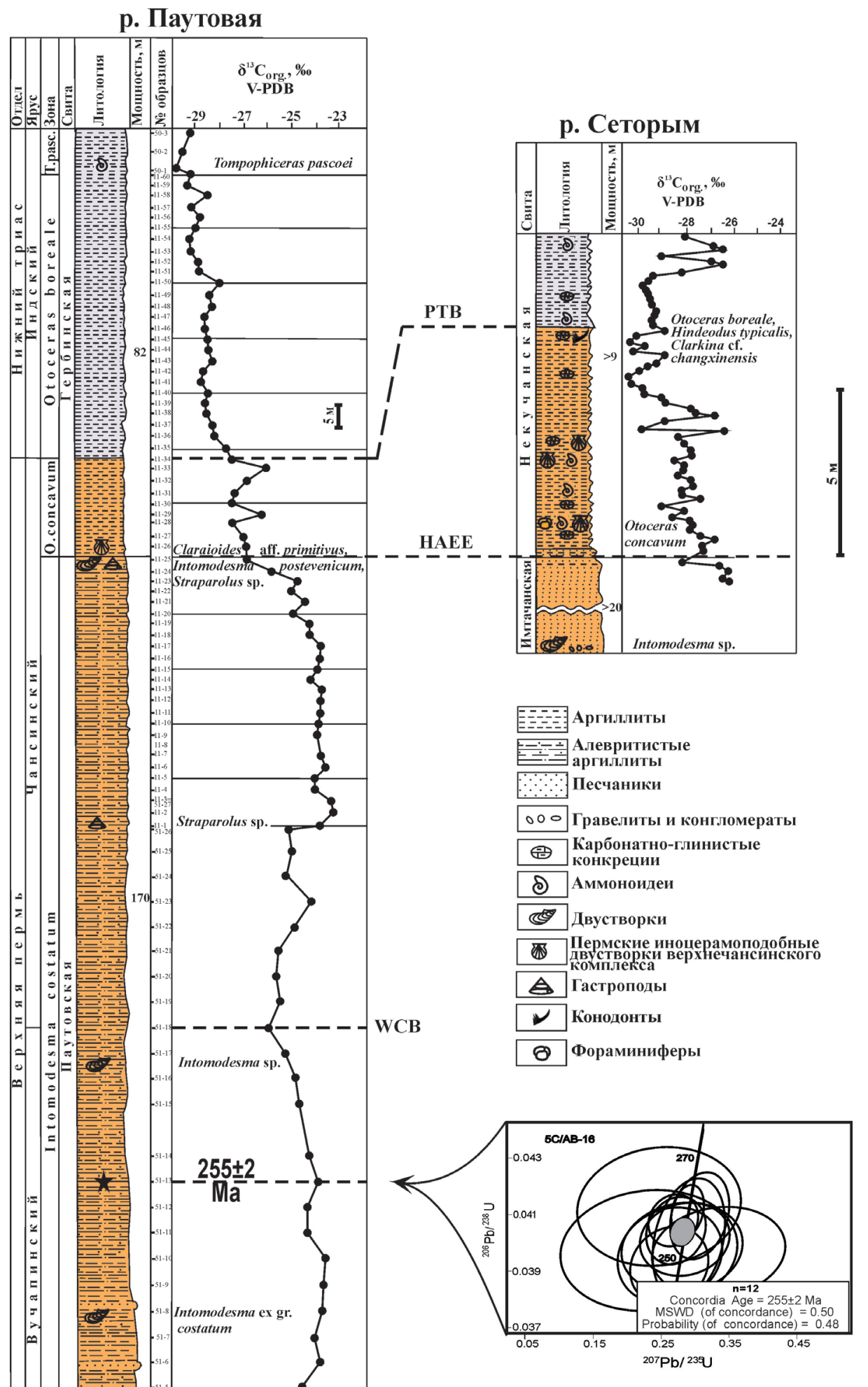

Puc. 3. Корреляция пограничных пермо-триасовых отложений Балыгычанского блока (р. Паутовая) и Южного Верхоянья (р. Сеторым). Ов. - оводовская свита; НАЕЕ - уровень события высокоарктического вымирания; РТВ - граница перми и триаса; WCB - граница вучапинского и чансинского ярусов; О. concavum - Otoceras concavum, T. pasc. - Tompophiceras pascoei. Звездочкой показана находка туфа в разрезе по р. Паутовая

Fig. 3. Correlation of Permian-Triassic boundary deposits of the Balygychan block (Pautovaya River) and Southern Verkhoyanye (Setorym River). Ов - Ovod formation; HAEE - High Arctic extinction event; PTB - Permian-Triassic boundary; WCB - Wuchiapingian-Changhsingian boundary; O. concavum - Otoceras concavum, T. pasc. - Tompophiceras pascoei. An asterisk marks the tuff found in the Pautovaya River section 


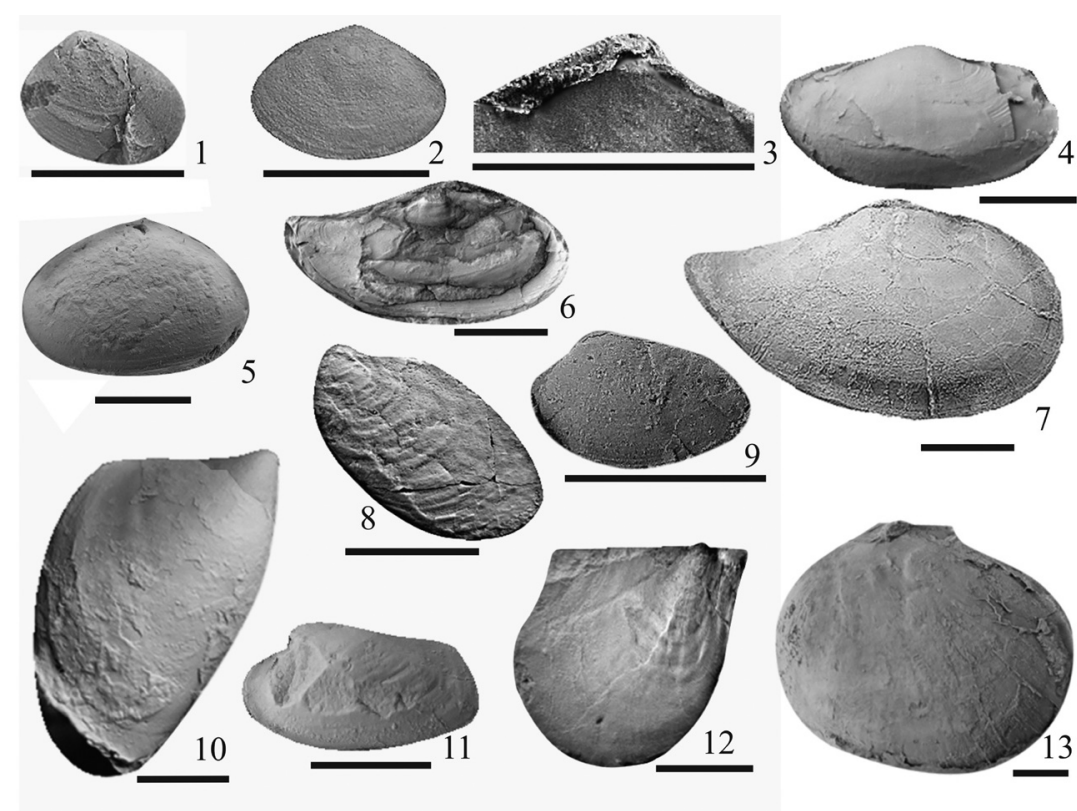

Рис. 4. Характерные представители двустворчатых моллюсков из пограничных пермо-триасовых отложений разреза Левый Суол (Южное Верхоянье). 1-3-Palaeоnисula aldanensis Kurushin; 4-Malletia ? sp. 1; 5-Sarepta ? sp.; 6, 7 - Dacryomya sp.; 8 - Maitaia cf. errabunda (Popow); 9 - Malletia? sp. 2; 10 - Myalina aff. putiatinensis (Kiparisova); 11 - Unionites cf. canalensis (Catullo); 12 - Pteria cf. ussurica (Kiparisova); 13 - Claraia sp. (Claraia aff. liuqiaoensis He et al.). Длина масштабной линейки 5 мм

Fig. 4. Characteristic bivalves from the Permian-Triassic boundary deposits of the Levy Suol section (Southern Verkhoyanye). 1-3-Palaeonucula aldanensis Kurushin; 4 - Malletia ? sp. 1; 5 - Sarepta ? sp.; 6, 7 -Dacryomya sp.; 8 - Maitaia cf. errabunda (Popow); 9 -Malletia ? sp. 2; 10 - Myalina aff. putiatinensis (Kiparisova); 11 - Unionites cf. canalensis (Catullo); 12 - Pteria cf. ussurica (Kiparisova); 13 - Claraia sp. (Claraia aff. liuqiaoensis He et al.). Scale bar $5 \mathrm{~mm}$

Ранее эта граница традиционно располагалась в основании отоцерасовых слоев (Tozer, 1967; Дагис, Дагис, 1987; и др.) и совпадала с началом крупной трансгрессии, как правило, фиксируясь резким изменением литологического состава пород и их текстурных особенностей.

На Северо-Востоке России эта граница в глубоководных непрерывных разрезах выражена полным исчезновением текстур биотурбации осадка и типичной высокобореальной бентосной фауны (гастропод-страпаролусов и гигантских иноцерамоподобных двустворок-интомодесм), появлением тонкой горизонтальной слоистости, изменением химического и минерального состава пород, появлением признаков аноксидных обстановок (Бяков, Ведерников, 1990, 2007; Бяков, 2004).

В настоящее время граница перми и триаса проводится по появлению конодонта Hindeodus parvus (Kozur et Pjatakova), принятого Международной триасовой подкомиссией в качестве маркера нижней границы мезозоя (Yin et al., 2001). Непосредственно ниже появления этих конодонтов во всех разрезах мира фиксируется крупный отрицательный экскурс изотопа $\delta^{13} \mathrm{C}$ (Algeo et al., 2012; Захаров и др., 2014, 2015; и др.). Поскольку находки конодонтов практически отсутствуют в высокобореальных разрезах, единственным маркером границы перми и триаса является именно этот экскурс.

В Южном Верхоянье (руч. Суол, басс. р. Сеторым) эта граница проходит в 6 м выше подошвы некучанской свиты (см. рис. 3), а на западе Балыгычанского блока - примерно в 20 м выше подошвы гербинской свиты. Подошвы упомянутых свит ранее рассматривались в качестве нижней границы триаса.

Еще одна важная граница вучапинско-чансинская определена с помощью сочетания хемостратиграфического метода и проведенного $\mathrm{U}-\mathrm{Pb}$ датирования туфа (255 \pm 2 млн лет, см. выше) на западе Балыгычанского блока (Бяков и др., 2017в) - см. рис. 3. Принимая во внимание положение датированного образца и сравнивая полученную запись изотопа $\delta^{13} \mathrm{C}_{\text {орг. }}$ с аналогичными записями $\delta^{13} \mathrm{C}_{\text {opr. }}$ в других разрезах, в частности, с разрезами Бучан Лейк в Арктической Канаде (Grasby, Beauchamp, 2009), Абаде в Иране (Liu et al., 2013), Янцзы в юго-восточном Китае (Liao et al., 2016), охарактеризованных конодонтами, мы можем наметить положение границы вучапинского и чансинского ярусов в изученном разрезе примерно на 30 м выше обнаруженного туфа - в средней части бивальвиевой зоны Intomodesma costatum.

\section{НОВЫЙ ПОЗДНЕЧАНСИНСКИЙ КОМПЛЕКС ДВУСТВОРЧАТЫХ МОЛЛЮСКОВ}

До последнего времени считалось, что наиболее молодой пермский комплекс ископаемой фауны происходит из бивальвиевой подзоны Intomodesma postevenicum и представлен преимущественно последними представителями типично высокобореальных родов иноцерамоподобных двустворчатых моллюсков - Maitaia, Intomodesma и гастроподами Straparolus sp., а также, вероятно, единичными Phestia, Palaeoneilo ?, Nuculopsis, "Streblopteria", Cunavella и Australomya (Бяков, 2010; Бяков и др., 2016, 2017в).

Поскольку современное положение границы перми и триаса оказалось несколько выше, чем считалось ранее (см. выше), возник вопрос, какова же палеонтологическая характеристика это- 
го интервала, отвечающего нижней части отоцерасовых слоев. Ранее отсюда были известны представители нектонной фауны аммоноидей Otoceras concavum Tozer и наутилид Tomponautilus setorymi Sobolev (Дагис и др., 1986), единичные бентосные двустворки Palaeonucula exigua Kurushin (Решения...., 2009), а с Балыгычанского блока - Claraioides aff. primitivus (Yin).

В результате целенаправленных трудоемких поисков ископаемой фауны недавно в бассейне p. Сеторым был выявлен совершенно новый ископаемый комплекс двустворок, приуроченный к основанию отоцерасовых слоев (Бяков и др., 2018). Этот комплекс включает Palaeonucula aldanensis Kurushin, Dacryomya sp., Malletia? sp. 1 и 2, Sarepta? sp., Myalina aff. putiatinensis (Kiparisova), Pteria cf. ussurica (Kiparisova), Maitaia cf. errabunda (Popow), Unionites cf. canalensis (Catullo).

По своему происхождению эта фауна имеет смешанный характер. Очевидно, что часть ее составляют местные таксоны, потомкам которых удалось пережить основной эпизод пермского вымирания (представители рода Maitaia и, вероятно, большинство протобранхий). Другая же часть (виды родов Myalina, Pteria и Unionites) представлена иммигрантами из надобласти Тетис, появившимися в Южно-Верхоянском бассейне вследствие глобальной трансгрессии конца чансинского века.

Особый интерес вызывает то, что многие определенные нами позднечансинские таксоны впервые были описаны из заведомо триасовых отложений (нижний триас Приморья; Кипарисова, 1938). Вероятные потомки многих из них (представители родов Palaeonucula, Dacryomya, Malletia, Sarepta, Myalina, Unionites) широко pacпространены на Севере Сибири в верхнеиндских - среднетриасовых отложениях (Дагис и др., 1996).

\section{ЗАКЛЮЧЕНИЕ}

Таким образом, за последние годы достигнут значительный прогресс в решении одной из наиболее важных задач пермской стратиграфии Северо-Востока России. Впервые с помощью использования высокоточных методов U-Pb датирования цирконов из синхронных осадконакоплению туфов удалось датировать ряд реперных уровней (около 10) из средне-верхнепермских отложений. Эти датировки позволили провести калибровку стратонов средней и верхней перми РСШ и в совокупности с изотопной хемостратиграфией $\delta^{13} \mathrm{C}_{\text {орг. }}$ впервые наметить границы верхнепермских стратонов МСШ на Северо-Востоке России.

Открытие самого молодого (позднечансинского) пермского комплекса двустворчатых моллюсков позволило дать палеонтологическую характеристику самым верхам перми и по-новому взглянуть на проблему великого позднепермского вымирания.

Работа выполнена при поддержке РФФИ, проект № 20-05-00604.

\section{ЛИТЕРАТУРА}

Брылькко И. В., Ползуненков Г. О., Бяков А. С. Новые U-Pb (SHRIMP-II) данные по циркону из среднепермских отложений Омолонского массива (СевероВосток России) // Осадочные планетарные системы позднего палеозоя: стратиграфия, геохронология, углеводородные ресурсы [Электрон. ресурс]: сб. тез. Междунар. стратиграф. конф. Головкинского-2019 (24-28 сент. 2019 г., Казань, Россия). Казань : Издво Казан. ун-та, 2019. С. 74-75. http://dspace.kpfu.ru/ xmlui/bitstream/handle/net/151929/golovkinsky2019.pdf

Бяков $A$. C. Биостратиграфия пермских отложений Северного Приохотья (Северо-Восток Азии) // Стратиграфия. Геол. корреляция. 2007. Т. 15, № 2. С. 47-71.

Бяков А. С. Зональная стратиграфия, событийная корреляция, палеобиогеография перми Северо-Востока Азии (по двустворчатым моллюскам). Магадан : СВКНИИ ДВО РАН, 2010. 262 с.

Бяков А. С. Морские двустворчатые моллюски Северо-Востока Азии на рубеже перми и триаса / Междунар. стратиграф. конф. Головкинского-2017 и Четвертая Всерос. конф. «Верхний палеозой России». Планетарные системы верхнего палеозоя: биостратиграфия, геохронология и углеводородные ресурсы (19-23 сент. 2017 г., Казань, Россия). Казань : Изд-во Казан. ун-та, 2017. С. 28-29.

Бяков А. С. Новая зональная схема пермских отложений Северо-Востока Азии по двустворчатым моллюскам. Ст. 1. Зональное расчленение // Тихоокеан. геол. 2012. Т. 31, № 5. С. 13-40.

Бяков А. С., Захаров Ю. Д., Хорачек М., Рихои С., Кутылин Р. В., Иванов Ю. Ю., Колесов Е. В., Константинов А. Г., Тучкова М. И., Михалицына Т. И. Новые данные о строении и возрасте терминальной перми Южного Верхоянья // Геология и геофизика. 2016. № 2. C. 91-105.

Бяков А. С., Горячев Н. А., Ведерников И. Л., Брынько И. В., Толмачева Е. В. Новые результаты $\mathrm{U}-\mathrm{Pb} \mathrm{SHRIMP}$ датирования цирконов из верхневучапинских (верхняя пермь) отложений Северо-Востока России // ДАН. 2017б. Т. 477, № 3. С. 331-336.

Бяков А. С., Кутьгин Р. В., Горячев Н. А., Бурнатный С. С., Наумов А. Н., Ядренкин А. В., Ведерников И. Л., Третьяков М. Ф., Брынько И. В. Открытие позднечансинского комплекса двустворок и два эпизода вымирания фауны в конце перми на Северо-Востоке Азии // ДАН. 2018. Т. 480, № 1. С. 121-124.

Бяков А. С., Horacek М., Горячев Н. А., Ведерников И. Л., Захаров Ю. Д. Первая детальная запись $\delta^{13} \mathrm{C}_{\text {org. }}{ }^{\text {в }}$ пограничных пермо-триасовых отложениях КолымоОмолонского региона (Северо-Восток Азии) // ДАН. 2017в. Т. 474, № 3. С. 347-350.

Бяков А. С., Шпикерман В. И., Ведерников И. Л., Толмачева E. В. Первые результаты U-Pb SIMS датирования цирконов из вучапинских (верхняя пермь) отложений Северо-Востока России: значение для межрегиональных корреляций // Стратиграфия. Геол. корреляция. 2017а. Т. 25, № 3. С. 19-28. 
Бяков А. C. Пермские отложения Балыгычанского поднятия (Северо-Восток Азии). Магадан : СВКНИИ ДВО РАН, 2004. $87 \mathrm{c}$.

Бяков А. С., Ведерников И. Л. Свидетельства аноксии на рубеже перми и триаса в глубоководных фациях на Северо-Востоке Азии // ДАН. 2007. Т. 417, № 5. C. 654-656.

Бяков А. С., Ведерников И. Л. Стратиграфия пермских отложений северо-восточного обрамления Охотского массива, центральной и юго-восточной частей Аян-Юряхского антиклинория : препринт. Магадан : СВКНИИ ДВО АН СССР, 1990. 69 с.

Ганелин В. Г., Котляр Г. В. Корреляция пермских отложений Биармийской области // Основные черты стратиграфии пермской системы СССР. Л. : Недра, 1984. C. 229-233.

Дагис А. С., Дагис А. А. Биостратиграфия древнейших отложений триаса и граница палеозоя и мезозоя // Геология и геофизика. 1987. № 1. С. 19-29.

Дагис А. С., Дагис А. А., Казаков А. М., Константинов А. Г., Курушин Н. И. Биостратиграфия нижнего инда Восточного Верхоянья // Биостратиграфия мезозоя Сибири и Дальнего Востока. Новосибирск : Наука, 1986. С. 21-31.

Дагис А. С., Дагис А. А., Ермакова С. П., Константинов А. Г., Курушин Н. И., Соболев Е. С., Трущелев A. M. Триасовая фауна Северо-Востока России. Новосибирск : Наука, 1996. 232 с.

Захаров Ю. Д., Бяков А. С., Хорачек М. Глобальная корреляция базальных слоев триаса в свете первых изотопно-углеродных свидетельств по границе перми и триаса на Северо-Востоке Азии // Тихоокеан. геол. 2014. № 1. C. 3-19.

Захаров Ю. Д., Бяков А. С., Хорачек М., Рихои С. Значение изотопно-углеродных данных по пограничным слоям перми и триаса в Верхоянье для глобальной корреляции базальных слоев триаса // Доклады PAH. 2015. T. 460, № 1. С. 60-64.

Кашик Д. С., Ганелин В. Г., Караваева Н. И., Бяков А. С., Миклухо-Маклай О. А., Стукалина Г. А., Ложкина Н. В., Дорофеева Л. А., Бурков Ю. К., Гутенева E. И., Смирнова Л. Н. Опорный разрез перми Омолонского массива. Л. : Наука, 1990. 200 с.

Кипарисова Л. Д. Нижнетриасовые пластинчатожаберные Уссурийского края // Тр. ГИН АН СССР. 1938. Т. 7. С. 197-310.

Решения Третьего межведомственного регионального стратиграфического совещания по докембрию, палеозою и мезозою Северо-Востока России (Санкт-Петербург, 2002) / ред. Т. Н. Корень, Г. В. Котляр. СПб. : Изд-во ВСЕГЕИ, 2009. 268 с.

Algeo T., Henderson C. M., Ellwood B., Rowe H., Elswick E., Bates S., Lyons T., Hower J. C., Smith C., Maynard B., Lindsay E., Hays L. E., Roger E., Summons R. E., Fulton J., Freeman K. H. Evidence for a diachronous Late Permian marine crisis from the Canadian Arctic region // GSA Bull. 2012. Vol. 124. P. 1424-1448.

Davydov V. I., Biakov A. S., Crowley J. L., Schmitz M. D., Isbell J. L., Vedernikov I. L. Middle Permian U-Pb zircon ages of the "glacial" deposits of the Atkan Formation, Ayan-Yuryakh anticlinorium, Magadan province, NE Russia: their significance for global climatic interpretations // Gondwana Res. 2016. Vol. 38. P. 74-85.

Davydov V. I., Biakov A. S., Schmitz M. D., Silantiev $V$. $V$. Radioisotopic calibration of the Guadalupian series: review and updates // Earth-Sci. Rev. 2018. Vol. 176. P. 222-240.

Durante $M . V$. The problem of the recognizing the "Changhsingian" in northeastern Asia (Boreal realm) // Permophiles. 2007. No. 49. P. 24-28.

Ganelin V. G., Biakov A. S. The F biostratigraphy of the Kolyma-Omolon region, Northeast Asia // J. Asian Earth Sci. 2006. Vol. 26, No. 3-4. P. 225-234.

Grasby S. E., Beauchamp B. Intrabasin variability of the carbon-isotope record across the Permian-Triassic transition, Sverdrup Basin, Arctic Canada // Chemical Geology. 2008. Vol. 253. P. 141-150.

Grasby S. E., Beauchamp B. Latest Permian to Early Triassic basin-to-shelf anoxia in the Sverdrup Basin, Arctic Canada // Chemical Geology. 2009. Vol. 264. P. 232-246.

Grasby S. E., Beauchamp B., Bond P. G. D., Wignal P., Talavera C., Galloway J. M., Piepjohn K., Reinhardt L., Blomeier D. Progressive environmental deterioration in northwestern Pangea leading to the latest Permian extinction // GSA Bull. 2015. Vol. 127. P. 1331-1347.

Isbell J. L., Biakov A. S., Vedernikov I. L., Davydov V. I., Gulbranson E. L., Fedorchuk N. D. Permian diamictites in Northeastern Asia: their significance concerning the bipolarity of the late Paleozoic ice age // Earth-Sci. Rev. 2016. Vol. 154. P. 279-300.

Krull E. S., Retallack G. J., Campbell H. J., Lyon G. L. Chemostratigraphy of the Permian-Triassic boundary in the Maitai Group, New Zealand: evidence for high-latitudinal methane release // New Zealand Journ. Geol. Geophys. 2000. Vol. 43. P. 21-32.

Kutygin R. V. Permian ammonoid associations of the Verkhoyansk Region, Northeast Russia // J. Asian Earth Sci. 2006. Vol. 26, No. 3-4. P. 243-257.

Liao Z., Hu W., Cao J., Wang X., Yao S., Wan Y. Permian-Triassic boundary (PTB) in the Lower Yangtze Region, southeastern China: A new discovery of deep-water archive based on organic carbon isotopic and $\mathrm{U}-\mathrm{Pb}$ geochronological studies // Palaeogeogr., Palaeoclimatol., Palaeoecol. 2016. Vol. 451. P. 124-139.

Liu X., Wang W., Shen S.-Z., Gorgij M. N., Ye F.-Ch., Zhang Y.-Ch., Furuyama S., Kano A., Chen X.-Zh. Late Guadalupian to Lopingian (Permian) carbon and strontium isotopic chemostratigraphy in the Abadeh section, central Iran // Gondwana Res. 2013. Vol. 24. P. 222-232.

Permian Timescale // Permophiles. 2019. Iss. 67. P. 64.

Tozer E. T. A standard for Triassic time // Bull. Geol. Surv. Canada. 1967. No. 156. P. 1-103.

Yin H., Zhang K., Tong J., Yang Z., Wu S. The Global Stratotype Section and Point (GSSP) of the Permian-Triassic boundary // Episodes. 2001. Vol. 24, No. 2. P. 102 114.

Поступила в редакцию 18.01.2020 2.

Поступила после доработки 22.01.2020 2. 


\title{
TOWARDS IMPROVING THE REGIONAL STRATIGRAPHIC SCALE FOR THE PERMIAN OF NORTHEAST RUSSIA: LATEST YEARS' RESULTS AND ACHIEVEMENTS
}

\author{
A. S. Biakov, I. L. Vedernikov, I. V. Brynko \\ North-East Interdisciplinary Scientific Research Institute n. a. N. A. Shilo, FEB RAS, Magadan \\ The problem of trans-regional correlation of the Permian Regional Stratigraphic Scale of Northeast \\ Russia (RSS) is still one of the most difficult tasks in the geology of Northeast Asia . Only recently, \\ due to the use of methods of precision (CA IDTIMS and SHRIMP-II) U-Pb dating of zircons from \\ synchronous sedimentation tuffs and methods of isotopic chemostratigraphy $\delta^{13} \mathrm{C}_{\text {org }}$, significant \\ progress has been made in this direction. For the first time, it was possible to reasonably determine \\ the position of the Permian-Triassic boundary, as it is currently understood, and to essentlally \\ correlate the Upper Permian stages of the RSS and the International Stratigraphic Scale. Also, the \\ youngest Permian (Late Changhsingian) bivalve complex was discovered.
}

Keywords: Regional stratigraphic scale, Permian, precision U-Pb dating of zircons, chemostratigraphy, $\delta^{13} C_{\text {org. }}$ isotopy, Northeast Russia.

\section{REFERENCES}

Algeo, T.; Henderson, C. M.; Ellwood, B.; Rowe, H.; Elswick, E.; Bates, S.; Lyons, T.; Hower, J. C.; Smith, C.; Maynard, B.; Lindsay, E.; Hays, L. E.; Roger, E.; Summons, R. E.; Fulton, J.; Freeman, K. H., 2012, Evidence for a Diachronous Late Permian Marine Crisis from the Canadian Arctic Region, GSA Bull., 124, 14241448.

Biakov, A. S., 2004, Permian Deposits of the Balygychan Uplift, Magadan, NEISRI FEB RAS [In Russian with English Summary].

Biakov, A. S., 2007, Permian Biostratigraphy of the Northern Okhotsk Region (Northeast Asia), Stratigraphy and Geological Correlation, 15 (2), 161-184.

Biakov, A. S., 2010, Zonal Stratigraphy, Event Correlation, Paleobiogeography of the Permian of Northeast Asian (Based on Bivalves), Magadan, NEISRI FEB RAS [In Russian with English Summary].

Biakov, A. S., 2012, A New Permian Bivalve Zonal Scale of Northeastern Asia. Article 1: Zonal Subdivision, Russian Journal of Pacific Geology, (5), 349-368.

Biakov, A. S., 2017, Marine Bivalves of Northeast Asia at the Permian-Triassic Boundary, Kazan Golovkinsky Stratigraphic Meeting-2017 and Fourth All-Russian Conference "Upper Palaeozoic of Russia": Upper Palaeozoic Earth Systems, High-Precision Biostratigraphy, Geochronology, and Petroleum Resources, Abstract Volume, Kazan, Kazan University, 28-29 [In Russian].

Biakov, A. S.; Goryachev, N. A.; Vedernikov, I. L.; Brynko, I. V.; Tolmachyova, Ye. V., 2017, New Results of U-Pb SHRIMP Dating of Zircons from Upper Wuchiapingian (Upper Permian) Deposits in Northeastern Russia, Doklady Earth Sciences, 477 (1), 1348-1352.

Biakov, A. S.; Horacek, M.; Goryachev, N. A.; Vedernikov, I. L.; Zakharov, Yu. D., 2017, The First Detailed $\delta^{13} \mathrm{C}_{\text {org. }}$ Record in Permo-Triassic Boundary Deposits in the Kolyma-Omolon Region (Northeast Asia), Doklady Earth Sciences, 474 (1), 591-594.

Biakov, A. S.; Kutygin, R. V.; Goryachev, N. A.; Byrnatny S. S.; Naumov, A. N.; Yadrenkin, A. V.; Vedernikov,
I. L.; Tretyakov, M. F.; Brynko, I. V., 2018, Discovery of the Late Changhsingian Bivalve Complex and Two Fauna Extinction Episodes in Northeastern Asia at the End of the Permian, Doklady Earth Sciences, 480, 78-81.

Biakov, A. S.; Shpikerman, V. I.; Vedernikov, I. L.; Zakharov, Yu. D., 2017, The First U-Pb TIMS Age Datings of Zircons from Upper Permian Deposits of the Northeastern Russia: Significance for Interregional Correlations, Stratigraphy and Geological Correlation, 25 (3), 256-264.

Biakov, A. S., Vedernikov, I. L., 1990. Stratigraphy of Permian Deposits of Northeast Framework of Okhotsk Massif, Central and Southeast Parts of Ayan-Yuryakh Antiklinorium, Magadan, NEISRI FEB RAS, 1-69 [In Russian].

Biakov, A. S.; Vedernikov, I. L., 2007, Evidence for Anoxia in a Deep Basin of Northeast Asia at the Permian - Triassic Transition, Doklady Earth Sciences, 417A (9), 1325-1327.

Biakov, A. S.; Zakharov, Yu. D.; Horacek, M.; Richoz, S.; Kutygin, R. V.; Ivanov, Yu. Yu; Kolesov, Ye. V.; Konstantinov, A. G.; Tuchkova, M. I.; Mikhalitsyna, T. I., 2016, New Data on the Structure and Age of the Terminal Permian Strata in the South Verkhoyansk Region (Northeastern Asia), Russian Geology and Geophysics, 57 (2), 282-293.

Brynko, I. V.; Polzunenkov, G. O.; Biakov, A. S., 2019, New U-Pb (SHRIMP-II) Data on Zircons from the Middle Permian of the Omolon Massif (Northeastern Russia), Abstract volume of Kazan Golovkinsky Stratigraphic Meeting, 2019 "Late Paleozoic Sedimentary Earth Systems: Stratigraphy, Geochronology, Petroleum Resources" (September 24-28, 2019), 74-75, http://dspace.kpfu. $\mathrm{ru} / \mathrm{xmlui} /$ bitstream/handle/net/151929/golovkinsky2019. pdf [In Russian].

Dagis, A. S.; Dagis, A. A., 1987, Biostratigraphy of the Oldest Triassic Deposits and the Paleozoic-Mesozoic Boundary, Russian Geology and Geophysics, 1, 19-20 [In Russian].

Dagis, A. S.; Dagis, A. A.; Kazakov, A. M.; Konstantinov, A. G.; Kurushin, N. I., 1986, Biostratigraphy of 
the Lower Induan Eastern Verkhoyanye, Biostratigraphy of Mesozoic in Siberia and Far East, Novosibirsk, Nauka, 21-31 [In Russian].

Dagis, A. S.; Dagis, A. A.; Ermakova, S. P.; Konstantinov, A. G.; Kurushin, N. I.; Sobolev, Ye. S.; Trushchelev, A. M., 1996, Triassic Fauna in the North-East of Russia, Novosibirsk, Nauka [In Russian].

Davydov, V. I.; Biakov, A. S.; Crowley, J. L.; Schmitz, M. D.; Isbell, J. L.; Vedernikov, I. L., 2016, Middle Permian U-Pb Zircon Ages of the "Glacial" Deposits of the Atkan Formation, Ayan-Yuryakh Anticlinorium, Magadan Province, NE Russia: Their Significance for Global Climatic Interpretations, Gondwana Res., 38, 74-85.

Davydov, V. I.; Biakov, A. S.; Schmitz, M. D.; Silantiev, V. V., 2018, Radioisotopic Calibration of the Guadalupian Series: Review and Updates, Earth-Sci. Rev., 176, 222-240.

Durante, M. V., 2007, The Problem of the Recognizing the "Changhsingian" in Northeastern Asia (Boreal Realm), Permophiles, 49, 24-28.

Ganelin, V. G.; Biakov, A. S., 2006, The F Biostratigraphy of the Kolyma-Omolon Region, Northeast Asia, $J$. Asian Earth Sci., 26 (3-4), 225-234.

Ganelin, V. G.; Kotlyar, G. V., 1984, Correlation of Permian Deposits in the Biarmian Realm Main Features of Stratigraphy of Permian System in the USSR, Leningrad, Nedra, 229-233 [In Russian].

Grasby, S. E.; Beauchamp, B., 2008, Intrabasin Variability of the Carbon-Isotope Record Across the Permian-Triassic Transition, Sverdrup Basin, Arctic Canada, Chemical Geology, 253, 141-150.

Grasby, S. E.; Beauchamp, B., 2009, Latest Permian to Early Triassic Basin-to-Shelf Anoxia in the Sverdrup Basin, Arctic Canada, Chemical Geology, 264, 232-246.

Grasby, S. E.; Beauchamp, B.; Bond, P. G. D.; Wignal, P.; Talavera, C.; Galloway, J. M.; Piepjohn, K.; Reinhardt, L.; Blomeier, D., 2015, Progressive Environmental Deterioration in Northwestern Pangea Leading to the Latest Permian Extinction, GSA Bull., 127, 1331-1347.

Isbell, J. L.; Biakov, A. S.; Vedernikov, I. L.; Davydov, V. I.; Gulbranson, E. L.; Fedorchuk, N. D., 2016, Permian Diamictites in Northeastern Asia: Their Significance Concerning the Bipolarity of the Late Paleozoic Ice Age, Earth-Sci. Rev., 154, 279-300.

Kashik, D. S.; Ganelin, V. G.; Karavayeva, N. I.; Biakov, A. S.; Miklukho-Maklay, O. A.; Stukalina, G. A.; Lozhkina, N. V.; Dorofeyeva, L. A.; Burkov, Yu. K.; Gutene- va, Ye. I.; Smirnova, L. N., 1990, Permian Key Section of the Omolon Massif, Leningrad, Nauka [In Russian].

Kiparisova, L. D., 1938, Lower Triassic Bivalves of the Ussuriland, Trudy GIN AS USSR, 7, 197-310 [In Russian].

Krull, E. S.; Retallack, G. J.; Campbell, H. J.; Lyon, G. L., 2000, Chemostratigraphy of the Permian-Triassic Boundary in the Maitai Group, New Zealand: Evidence for High-Latitudinal Methane Release, New Zealand Journ. Geol. Geophys., 43, 21-32.

Kutygin, R. V., 2006, Permian Ammonoid Associations of the Verkhoyansk Region, Northeast Russia, $J$. Asian Earth Sci., 26 (3-4), 243-257.

Liao, Z. ; Hu, W. ; Cao, J. ; Wang, X.; Yao, S.; Wan Y., 2016, Permian-Triassic Boundary (PTB) in the Lower Yangtze Region, Southeastern China: A New Discovery of Deep-water Archive Based on Organic Carbon Isotopic and U-Pb Geochronological Studies, Palaeogeogr., Palaeoclimatol., Palaeoecol., 451, 124-139.

Liu, X.; Wang, W.; Shen, S.-Z.; Gorgij, M. N.; Ye, F.-Ch.; Zhang, Y.-Ch.; Furuyama; S.; Kano, A.; Chen, $X$.-Zh., 2013, Late Guadalupian to Lopingian (Permian) Carbon and Strontium Isotopic Chemostratigraphy in the Abadeh Section, Central Iran, Gondwana Res., 24, 222-232.

Permian Timescale, 2019, Permophiles, 67, 64.

Resolutions of the Third Cross-Ministerial Regional Stratigraphic Meeting of Pre-Cambrian, Paleozoic, and Mesozoic in Russia's North-East (St. Petersburg, 2002), 2009, Eds. T. N. Koren, G. V. Kotlyar, St. Petersburg, VSEGEI [In Russian].

Tozer, E. T., 1967, A Standard for Triassic Time, Bull. Geol. Surv. Canada, 156, 1-103.

Yin, H.; Zhang, K.; Tong, J.; Yang, Z.; Wu, S., 2001, The Global Stratotype Section and Point (GSSP) of the Permian-Triassic Boundary, Episodes, 24 (2), 102114.

Zakharov, Yu. D.; Biakov, A. S.; Horacek, M., 2014, Global Correlation of Basal Triassic Layers in the Light of the First Carbon Isotope Data on the Permian-Triassic Boundary in Northeast Asia, Russian Journal of Pacific Geology, 8, 1-17.

Zakharov, Yu. D.; Biakov, A. S.; Horacek, M.; Richoz, S., 2015, Importance of Carbon Isotopic Data of the Permian-Triassic Boundary Layers in the Verkhoyansk Region for the Global Correlation of the Basal Triassic Layer, Doklady Earth Sciences, 460 (1), 1-5. 